\title{
ANTIFUNGAL ACTIVITY OF MEDICINAL PLANT EXTRACTS AGAINST PHYTOPATHOGENIC FUNGUS Alternaria SPP.
}

\author{
Paola Díaz Dellavalle ${ }^{1}$, Andrea Cabrera ${ }^{1}$, Diego Alem¹, Patricia Larrañaga ${ }^{1}$, Fernando Ferreira ${ }^{2}$, \\ and Marco Dalla Rizza ${ }^{1^{*}}$
}

\begin{abstract}
The aim of the study was to evaluate the antifungal activity of extracts of 10 plant species used in traditional Uruguayan medicine against the phytopathogenic fungus Alternaria spp. The plants were selected on the basis of their reported ethnobotanical uses. Aqueous, saline buffer and acid extracts of different plant species were screened in vitro for their antifungal activity against Alternaria spp. For the antifungal evaluation we used a microspectrophotometric assay. Minimal inhibitory concentration (MIC) and minimum fungicidal concentration (MFC) of the extracts were determined. Three solvents were assayed on different tissues of the plants and among the 29 evaluated extracts, $31 \%$ of the extracts inhibited growth, similar to the effects of a chemical fungicide. Acid extracts of the plants were more effective than the aqueous or buffer extracts against Alternaria spp. The MIC values of the extracts were determined ranging between 1.25 and $25 \mu \mathrm{g} \mathrm{mL}^{-1}$. The MFC values of the extracts ranged between $1.25 \mu \mathrm{g} \mathrm{mL}^{-1}$ (Rosmarinus officinalis L.) and $10 \mu \mathrm{g} \mathrm{mL}^{-1}$ (Cynara scolymus L.). MICs and MFCs values obtained from leaves (Salvia officinalis L. and $R$. officinalis) and seeds extracts (Salvia sclarea $\mathrm{L}$.) were quite comparable to values obtained with the conventional fungicide captan $\left(2.5 \mu \mathrm{g} \mathrm{mL}^{-1}\right)$. The extracts of Salvia sclarea, S. officinalis and R. officinalis could be considered as potential sources of antifungal compounds for treating diseases in plants. These extracts showed maximum activity, even at very low concentrations, and the same fungicide effects as chemical fungicide. We conclude from this that these extracts exhibit amazing fungicidal properties that support their traditional use as antiseptics.
\end{abstract}

Key words: Fungicidal properties, ethnobotanical uses, Uruguay.

$P$ athogenic fungi are the main infectious agents in plants, causing alterations during developmental stages including post-harvest. In fruit and vegetables, there is a wide variety of fungal genera causing quality problems related to aspect, nutritional value, organoleptic characteristics, and limited shelf life (Agrios, 2004). In addition, in some cases fungi are indirectly responsible for allergic or toxic disorders among consumers because of the production of mycotoxins or allergens.

Generally, phytopathogenic fungi are controlled by synthetic fungicides; however, the use of these is increasingly restricted due to the harmful effects of pesticides on human health and the environment (Harris

${ }^{1}$ Instituto Nacional de Investigación Agropecuaria (INIA Las Brujas), Ruta 48 km 10, Canelones, Uruguay.

*Corresponding author (mdallarizza@inia.org.uy).

${ }^{2}$ Universidad de la República, Facultad de Química, Av. General Flores 2124, Montevideo, Uruguay.

Received: 2 August 2010.

Accepted: 26 December 2010. et al., 2001). The increasing demand of production and regulations on the use of agrochemicals and the emergence of pathogens resistant to the products employed, justifies the search for novel active molecules and new control strategies.

Since antiquity, the plant kingdom has provided a variety of compounds of known therapeutic properties, like analgesics, anti-inflammatories, medicines for asthma, and others. In recent years, antimicrobial properties of plant extracts have been reported with increasing frequency from different parts of the world (Cowan, 1999). For example, a large proportion of the South American population use plant extracts obtained from traditional medicinal plants as medicine for many infectious diseases. Plants from the genus Pterocaulon, known as "quitoco", are commonly used in veterinary medicine in southern Brazil to treat animal problems popularly diagnosed as "mycoses" (Demo and Oliva, 2008). Several works have demonstrated in laboratory trials that different plant tissues, such as roots, leaves, 
seeds and flowers possess inhibitory properties against bacteria, fungi and insects (Davicino et al., 2007). Currently, there is little evidence on the antimicrobial properties of the medicinal plants under investigation against phytopathogen fungi.

Fungi are ubiquitous in the environment, and infection due to fungal pathogens has become more common. The genus Alternaria Nees is widely distributed in nature and its species are among the most common fungi on the phyllosphere (Lopes and Martins, 2008). It includes both plant-pathogenic and plant-saprophytic species that may damage crops in the field or cause post-harvest decay (Griffin and Chu, 1983), causing considerable economics losses for farmers and food industries. In addition, the genus produces mycotoxins and phytotoxins, and studies in the last decade have emphasized its toxicogenic properties rather than simply those that cause spoilage. The toxins alternariol, alternariol methyl ether, altenuene, and tenuazonic acid are known as possible food contaminants with potential toxicological risk (Pose et al., 2004). The aim of this work was to evaluate in vitro the potential antifungal activity of medicinal Uruguayan plant extracts against Alternaria spp., in order to verify possible inhibition activity. As well, the smallest concentration capable of inhibiting or preventing growth was determined among the species and extracts that demonstrated inhibitory properties.

\section{MATERIALS AND METHODS}

\section{Plant material}

Different plant tissues from plant species used in traditional medicine (Table 1) were collected in 2008 in their natural habitat in Uruguay. The collected plants were identified at the Department of Vegetal Protection of the Instituto Nacional de Investigación Agropecuaria (INIA Las Brujas), Canelones, Uruguay.

\section{Preparation of plant extracts}

Seed and flower samples were thoroughly washed and ground to a fine powder in liquid nitrogen, using a mortar and pestle. Leaf samples were dried under forced circulation of heated air at $40{ }^{\circ} \mathrm{C}$ to reduce deterioration of the plant drug material and ground to powder in liquid nitrogen, using a mortar and pestle. The powder from all the samples was carefully stored a $-20^{\circ} \mathrm{C}$.

Water-soluble extracts were prepared as described by Rivillas-Acevedo and Soriano-García (2007), with some modifications. The powdered material $(2 \mathrm{~g})$ of all plants was extracted for $1 \mathrm{~h}$ at $4{ }^{\circ} \mathrm{C}$ with water (ratio 1:10) under stirring conditions. The homogenate was filtered through double-layered muslin cloth and clarified by centrifugation at $7000 \times \mathrm{g}$ for $30 \mathrm{~min}$ at $4{ }^{\circ} \mathrm{C}$. The supernatant was sterilized by filtration through $0.22 \mu \mathrm{m}$ sterile filters (Millipore, Bedford, Massachusetts, USA) and stored at $-20{ }^{\circ} \mathrm{C}$ until further use. The resulting aqueous solution (Extract $\mathrm{A}$ ) was used for the fungal growth inhibition assay.

The methodology of Terras et al. (1992) with modifications was used to process the buffer extracts from the plants of interest. The powdered material $(2 \mathrm{~g})$ of all plants was extracted for $1 \mathrm{~h}$ at $4{ }^{\circ} \mathrm{C}$ under continuous stirring with an ice-cold extraction buffer (ratio 1:10) containing $10 \mathrm{mM} \mathrm{NaH} \mathrm{PO}_{4}, 15 \mathrm{mM} \mathrm{Na} \mathrm{HPO}_{4}, 100 \mathrm{mM}$ $\mathrm{KCl}, 2 \mathrm{mM}$ EDTA, $1.5 \%$ (w/v) polyvinylpolypyrrolidone (PVPP), $1 \mathrm{mM}$ phenylmethylsulfonylfluoride (PMSF) and $1 \mathrm{mg} \mathrm{L}^{-1}$ Pepstatin A. The homogenate was filtered through double-layered muslin cloth and clarified by centrifugation at $7000 \times \mathrm{g}$ for $30 \mathrm{~min}$ at $4{ }^{\circ} \mathrm{C}$. The supernatant was sterilized by filtration through $0.22 \mu \mathrm{m}$ sterile filters (Millipore) and stored at $-20^{\circ} \mathrm{C}$ until further use. The resulting buffer test solution (Extract B) was used for the fungal growth inhibition test.

To obtain acid extracts, the powdered material (2 g) of all plants was extracted (ratio 1:10) with 10\% $(\mathrm{v} / \mathrm{v})$ acetic acid for $1 \mathrm{~h}$ on a magnetic stirrer at room temperature (Lipkin et al., 2005). The homogenate was filtered through double-layered muslin cloth and clarified by centrifugation at $7000 \times \mathrm{g}$ for $30 \mathrm{~min}$ at $4{ }^{\circ} \mathrm{C}$. The supernatants were lyophilized to remove the solvent and kept in a freezer at $-20^{\circ} \mathrm{C}$. Before the antifungal testing the lyophilizate was resuspended in distilled water and sterilized by filtration through $0.22 \mu \mathrm{m}$ sterile filters (Millipore); resulting in the acid test solution (Extract C).

\section{Determination of extraction yield ( $\%$ yield)}

The yield $(\%, w / w)$ from all the dried extracts was calculated as:

$$
\text { Yield }(\%)=\left(\mathrm{W}_{1} * 100\right) / \mathrm{W}_{2}
$$

where $\mathrm{W}_{1}$ is the weight of the extract after lyophilization of solvent, and $\mathrm{W}_{2}$ is the weight of the plant powder.

\section{Fungal strain}

Strains of Alternaria spp. were obtained from the Plant Protection Department of the Instituto Nacional de Investigación Agropecuaria (INIA Las Brujas). The fungus was grown at $27{ }^{\circ} \mathrm{C}$ on potato dextrose agar (PDA) (OXOID, Hampshire, England). Spores of the fungus were collected from cultures on agar plates after 7 d as described by Broekaert et al. (1990). The sporangial suspension concentration was estimated using a cellcounting chamber and adjusted to $2 \times 10^{6}$ spores $\mathrm{mL}^{-1}$ (Abril et al., 2008). The fungal spore suspensions were stored in $20 \%$ glycerol at $-40{ }^{\circ} \mathrm{C}$. 
Table 1. List of medicinal plants used in this work with the popular uses in Uruguay.

\begin{tabular}{|c|c|c|c|}
\hline Species (family) & Local name & Popular uses $^{\text {a }}$ & Organ used \\
\hline $\begin{array}{l}\text { Lonicera japonica Thunb. } \\
\text { (Caprifoliaceae) }\end{array}$ & Madreselva & $\begin{array}{l}\text { Antibacterial, antiviral, diuretic, anti-inflammatory, } \\
\text { febrifuge, antispasmodic. }\end{array}$ & Flowers \\
\hline $\begin{array}{l}\text { Baccharis trimera (Less.) } \\
\text { DC. (Asteraceae) }\end{array}$ & Carqueja & $\begin{array}{l}\text { Hepatoprotective, anti-acid, anti-inflammatory, digestive, } \\
\text { carminative, diuretic, antihelmintic. }\end{array}$ & Leaves \\
\hline Zea mays L. (Poaceae) & Maíz dulce & Diuretic, anti-inflammatory, analgesic, against colds & Seeds \\
\hline $\begin{array}{l}\text { Cynara scolymus L. (Le) } \\
\text { (Asteraceae) }\end{array}$ & Alcaucil & $\begin{array}{l}\text { Digestive, diuretic, cardiotonic, hypotensive, } \\
\text { anticholesterolemic. }\end{array}$ & Seeds \\
\hline $\begin{array}{l}\text { Salvia sclarea } \mathrm{L} \text {. } \\
\text { (Lamiaceae) }\end{array}$ & Salvia moscatel & Antiseptic, sedative, antidepressant and hypotensive. & Seeds \\
\hline $\begin{array}{l}\text { Salvia officinalis L. (Le) } \\
\text { (Lamiaceae) }\end{array}$ & Salvia & $\begin{array}{l}\text { Antiseptic, facilitator of digestion. External use: } \\
\text { antiseptic, anti-inflammatory and healing properties. }\end{array}$ & Leaves \\
\hline $\begin{array}{l}\text { Rosmarinus officinalis L. } \\
\text { (Le) (Lamiaceae) }\end{array}$ & Romero & $\begin{array}{l}\text { Antiseptic, antispasmodic, diuretic. The essence is } \\
\text { nervous stimulant, carminative. In external use for } \\
\text { rheumatism, muscle aches, skin problems. }\end{array}$ & Leaves \\
\hline $\begin{array}{l}\text { Schinus molle L. } \\
\text { (Anacardiaceae) }\end{array}$ & $\begin{array}{l}\text { Anacahuita o } \\
\text { falso pimiento }\end{array}$ & $\begin{array}{l}\text { Analgesic, antidepressant, antispasmodic, antimicrobial, } \\
\text { astringent, diuretic, stimulant. }\end{array}$ & Leaves \\
\hline $\begin{array}{l}\text { Aloe vera }(\mathrm{L} .) \text { Burm. f. } \\
\text { (Asteraceae) }\end{array}$ & Aloe & $\begin{array}{l}\text { Laxative, hepatic diseases. In external use for } \\
\text { inflammatory disorders, burns, eczema. Very effective in } \\
\text { fighting infections and healing wounds. }\end{array}$ & Seeds \\
\hline $\begin{array}{l}\text { Lippia alba (Mill.) } \\
\text { N.E. Br. ex Britton \& P. } \\
\text { Wilson (Verbenaceae) }\end{array}$ & Salvia trepadora & Sedative, expectorant, digestive, antispasmodic. & Leaves \\
\hline
\end{tabular}

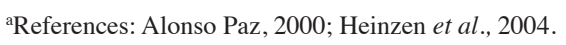

\section{Determination of antifungal activity}

Antifungal activity was measured by a quantitative microspectrophotometric assay (Broekaert et al., 1990). Growth inhibition was measured in 96-well microtiter plates at $595 \mathrm{~nm}$. Routinely, tests were performed with $20 \mu \mathrm{L}$ of the extract to be assayed, $10 \mu \mathrm{L}$ of a spore suspension and $70 \mu \mathrm{L}$ of potato dextrose broth (PDB) (HiMedia, Mumbai, India). Microcultures containing 20 $\mu \mathrm{L}$ of sterile distilled water instead of test solution were used as a negative control. The commercial fungicide captan ( $N$-(trichloromethylthio)cyclohex-4-ene-1,2dicarboximide) at $0.2 \mathrm{mg} \mathrm{mL}^{-1}$ (Satish et al., 2007) was used as a positive control. The plates were left standing for $30 \mathrm{~min}$ at $27^{\circ} \mathrm{C}$ to allow the spores to sediment, after which absorbance was measured at $595 \mathrm{~nm}$ in an ELISA plate reader. After $48 \mathrm{~h}$ of incubation at $27{ }^{\circ} \mathrm{C}$, growth was recorded by measuring absorbance. All assays for antifungal activity were carried out at least in triplicate. Growth inhibition (Broekaert et al., 1990) was determined based on the equation $[(\Delta \mathrm{C}-\Delta \mathrm{T}) / \Delta \mathrm{C}] \times 100$, where $\Delta \mathrm{C}$ is the corrected absorbance of the control microculture at $595 \mathrm{~nm}$ and $\Delta \mathrm{T}$ is the corrected absorbance of the test microculture. The corrected absorbance values equal the absorbance at $595 \mathrm{~nm}$ of the culture measured after $48 \mathrm{~h}$ minus the absorbance at $595 \mathrm{~nm}$ measured after $30 \mathrm{~min}$.

Minimal inhibitory concentration (MIC) and minimum fungicidal concentration (MFC)

A microplate method, as previously described (Eloff, 1998), was used with slight modifications to determine minimal inhibitory concentration (MIC) values of plant extracts. Plant extracts were serially diluted, ranging from $1 / 2$ up to a $1 / 100$ dilution from the crude extract. In each well, $100 \mu \mathrm{L}$ of each extract dilution was mixed with 100 
$\mu \mathrm{L}$ of the fungal spore suspension $\left(2 \times 10^{6}\right.$ spores $\mathrm{mL}^{-1}$ in fresh PDB). The microplates were incubated for $2-3$ d at $27{ }^{\circ} \mathrm{C}$ with daily monitoring. All experiments were done in triplicate. The MIC readings were performed spectrophotometrically with a microplate reader at 595 $\mathrm{nm}$. MICs values were calculated by comparing growth in control wells and the extract blank, which consisted of uninoculated plates. The MIC of the extracts was defined as the lowest concentration of plant extract that caused growth inhibition of more than $90 \%$ at $48 \mathrm{~h}$, as compared to the control.

The in vitro fungicidal activity (MFC) was determined described by Espinel-Ingroff et al. (2002). After $72 \mathrm{~h}$ of incubation, $20 \mu \mathrm{L}$ was subcultured from each well that showed no visible growth (growth inhibition of over 98\%), from the last positive well (growth similar to that for the growth control well), and from the growth control (extract-free medium) onto PDA plates. The plates were incubated at $27{ }^{\circ} \mathrm{C}$ until growth was seen in the growth control subculture. The minimum fungicidal concentration was regarded as the lowest extract concentration that did not yield any fungal growth on the solid medium used.

\section{RESULTS AND DISCUSSION}

The present study tested the antifungal activity of crude extracts and their respective dilutions from medicinal plants belonging to seven plant families against Alternaria sp. These medicinal plants were chosen based on either traditional usage (Table 1), suggestive of antimicrobial activity, or previous studies that have demonstrated antifungal properties using different kinds of extracts (Guo et al., 1997; Wilson et al., 1997; Zhu et al., 2005). Of the 29 extracts evaluated, $31 \%$, from nine plants, exhibited in vitro antifungal activity, with inhibition values of over $90 \%$. The species with the most pronounced antifungal activity were buffer extract of $C$. scolymus, acid extracts of S. sclarea, S. officinalis and buffer and acid extracts of Lippia alba, with 98\% growth inhibition of Alternaria.

Table 2 shows the extraction yields for the aqueous and acid plant extracts. The extraction yields varied from $8.6 \%$ to $41.9 \%$ and $0.7 \%$ to $42.2 \%$, respectively. A wide range of the yields among extracts was observed depending on the extraction solvent and plant material used. Schinus molle exhibited the lowest extraction yield of $0.7 \%$ (acid extraction). The maximum extraction yield was obtained from seeds of $S$. sclarea, with $42.2 \%$ (acid extraction).

Aqueous, buffer and acid extracts of 10 plant species were screened in vitro for their antifungal activity against Alternaria sp. The growth inhibition for the crude extracts was measured (Figure 1). Among the 29 extracts evaluated, 13 (45\%), belonging to eight plant species,
Table 2. Percentage extract yield of medicinal plants used.

\begin{tabular}{lcc}
\hline Plant species & Extract $^{\mathbf{a}}$ & $\begin{array}{c}\text { Extract } \\
\text { yield (\%) }\end{array}$ \\
\hline Lonicera japonica & $\mathrm{A}$ & 8.6 \\
Baccharis trimera & $\mathrm{C}$ & 2.6 \\
Zea mays & $\mathrm{A}$ & 28.9 \\
& $\mathrm{C}$ & 23.3 \\
Cynara scolymus & $\mathrm{A}$ & 25.6 \\
Salvia sclarea & $\mathrm{C}$ & 28.4 \\
& $\mathrm{~A}$ & 29.2 \\
Salvia officinalis & $\mathrm{C}$ & 9.9 \\
\multirow{2}{*}{ Rosmarinus officinalis } & $\mathrm{A}$ & 41.9 \\
& $\mathrm{C}$ & 42.2 \\
Schinus molle & $\mathrm{A}$ & 18.6 \\
& $\mathrm{C}$ & 29.4 \\
Aloe vera & $\mathrm{A}$ & 20.4 \\
Lippia alba & $\mathrm{A}$ & 23.5 \\
& $\mathrm{C}$ & 34.5 \\
& $\mathrm{~A}$ & 0.7 \\
& $\mathrm{C}$ & 41.1 \\
& $\mathrm{~A}$ & 39.0 \\
& $\mathrm{C}$ & 17.6 \\
& & 28.1 \\
\hline
\end{tabular}

${ }^{\mathrm{a} E x t r a c t: ~ A: ~ a q u e o u s ; ~ C: ~ a c i d i c . ~}$

showed percentages of inhibition above $75 \%$. Nine extracts (31\%), belonging to seven plant species, showed similar inhibition values as those of the commercial fungicide used as a positive control, with inhibition rates of over $90 \%$.

A high percentage of the water extracts $(80 \%)$ did not exhibit antifungal activity, only Zea mays and Cynara scolymus extracts were active. However, all the buffer and acid extracts were found to have activity against Alternaria sp., with a wide range of percentages, from $11.1 \%$ to $99.9 \%$. As can be seen, acid extracts generally possessed more activity than buffer extracts.

Cynara scolymus was the only species whose three different extracts inhibited fungal growth, with inhibition rates ranging from $78 \%$ to $98 \%$. This suggests that the active biomolecule of $C$. scolymus is soluble in aqueous solvents and has a different affinity to the solvents assayed. By contrast, the extracts of Lonicera japonica exhibited the lowest percentages of inhibition.

The average extraction yield in water and acetic acid, $26.6 \%$ and $22.7 \%$, respectively, were quite similar, indicating that for the procedure of extraction detailed in the material and methods section, both extracts were efficient in dissolving cellular components. Nevertheless, these soluble substances were not responsible for the 


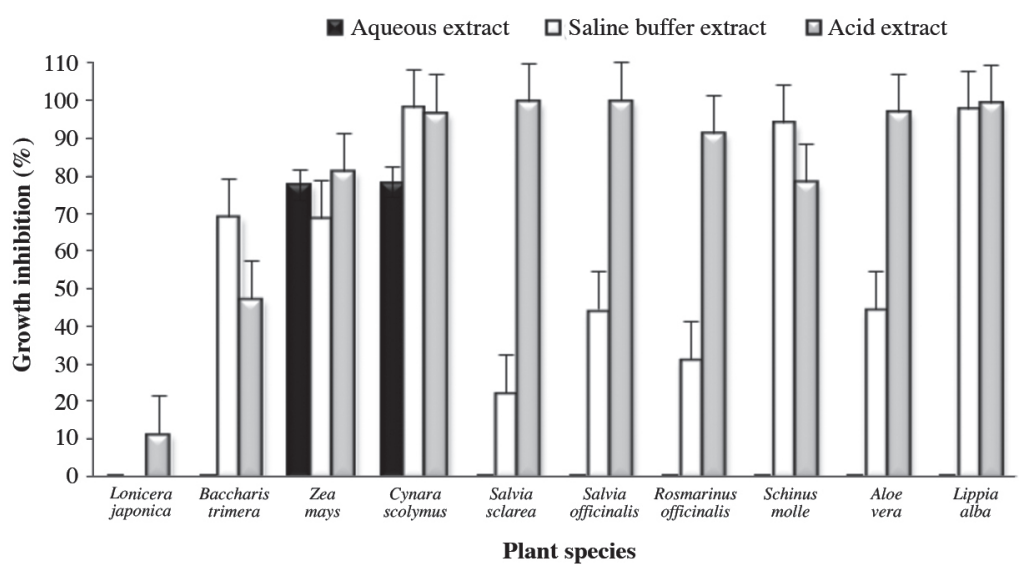

Figure 1. Growth inhibition of Alternaria sp. by crude extracts of traditional Uruguayan medicinal plants.

antifungal activity. Acid extraction had the lowest average yield, but conversely the highest average growth inhibition $(80 \%)$.

The effect of different dilutions of the plant extracts against Alternaria sp. is summarized in Table 3. Two of the aqueous extract dilutions (dilution 1/10), five buffer extract dilutions (ranging from dilution $1 / 2$ to dilution $1 / 10$ ) and 19 acid extracts dilutions (ranging from dilution $1 / 2$ to $1 / 40$ ) inhibited growth of Alternaria sp. by more than $90 \%$. The acid extracts of S. sclarea, S. officinalis and $R$. officinalis showed growth inhibition at concentrations as low as $1 / 40$ dilution.

Minimal inhibitory concentration (MIC) and minimum fungicidal concentration (MFC) were established for aqueous, buffer and acid extracts from each of the 10 species. Table 4 shows MICs and MFCs of active plant extracts. From the total extracts evaluated, 12 showed fungistatic activity and four showed fungicidal activity. The MIC values ranged from 1.25 to $25.0 \mu \mathrm{g} \mathrm{mL}^{-1}$ and MFCs values ranged from 1.25 to $10.0 \mu \mathrm{g} \mathrm{mL}^{-1}$. Acid extracts of S. sclarea, S. officinalis and R. officinalis had the lowest MIC $\left(1.25 \mu \mathrm{g} \mathrm{mL}^{-1}\right)$, while buffer extracts of Schinus molle and L. alba, and acid extracts of Aloe vera and $L$. alba had the highest MIC $\left(25.0 \mu \mathrm{g} \mathrm{mL}^{-1}\right)$. The MIC of aqueous, buffer and acid extracts of $C$. scolymus were 5.0, 10.0 and $10.0 \mu \mathrm{g} \mathrm{mL} \mathrm{m}^{-1}$, respectively, and amazingly it was the only species whose three extracts showed fungistatic activity. The minimum fungicidal concentration of the acid extract of $R$. officinalis proved to posses the highest fungicidal action against Alternaria $\mathrm{sp}$. as indicated by the low value $\left(1.25 \mu \mathrm{g} \mathrm{mL}^{-1}\right.$, Table 4$)$.

According to the results obtained, the extraction yields of water and acid extracts are quite similar. However, greater efficiency in the extraction of solutes is not directly related to greater inhibition. In this regard, acid extracts proved to have more activity against Alternaria than aqueous extracts. Thus, it can be concluded that acetic acid was more efficient in the extraction of water-soluble biomolecules with antifungal activity. The aqueous extracts that demonstrated the least activity against Alternaria spp. could be explained by the fact that when plant materials are ground in water, some phenolases and hydrolases are released and could have modulating effects on the activity of the compounds in the extracts. It could also be due to incomplete extraction of the active principles (El-Mahmood et al., 2008). Our results are in accordance with Pinelo et al. (2004), who suggested the that chemical characteristics of the solvent, the method used during the extraction process and diverse structural and compositional aspects of the natural products result in each materialsolvent system showing distinct behaviour. Differences in polarity among various solvents have been reported to account for the differences in solubility of active plant active properties, hence variations in the degree of activity. For example, Itako et al. (2008) reported 60\% inhibition of Alternaria solani germination when using $R$. officinalis aqueous extract, whereas in the present work $R$. officinalis aqueous extract did not inhibit the growth of Alternaria spp. On the other hand, R. officinalis acid extract showed $91.2 \%$ of growth inhibition.

Comparison of the growth inhibition of the crude extracts and their respective dilutions shows a strong dependent effect on extract concentrations. In general, the antifungal activity of extract dilutions is weaker compared to crude extracts. These results revealed that antifungal activity of the crude extracts was enhanced by increasing the concentration of the extracts, in effect, the inhibition activity of the extracts was concentration dependent. This finding is in agreement with the report of Banso et al. (1999), who also observed that higher concentrations of antimicrobial substances showed more growth inhibition.

In addition, the antimicrobial activity of plant extracts might not be due to the action of a single active compound, but the synergistic effect of several compounds that are 


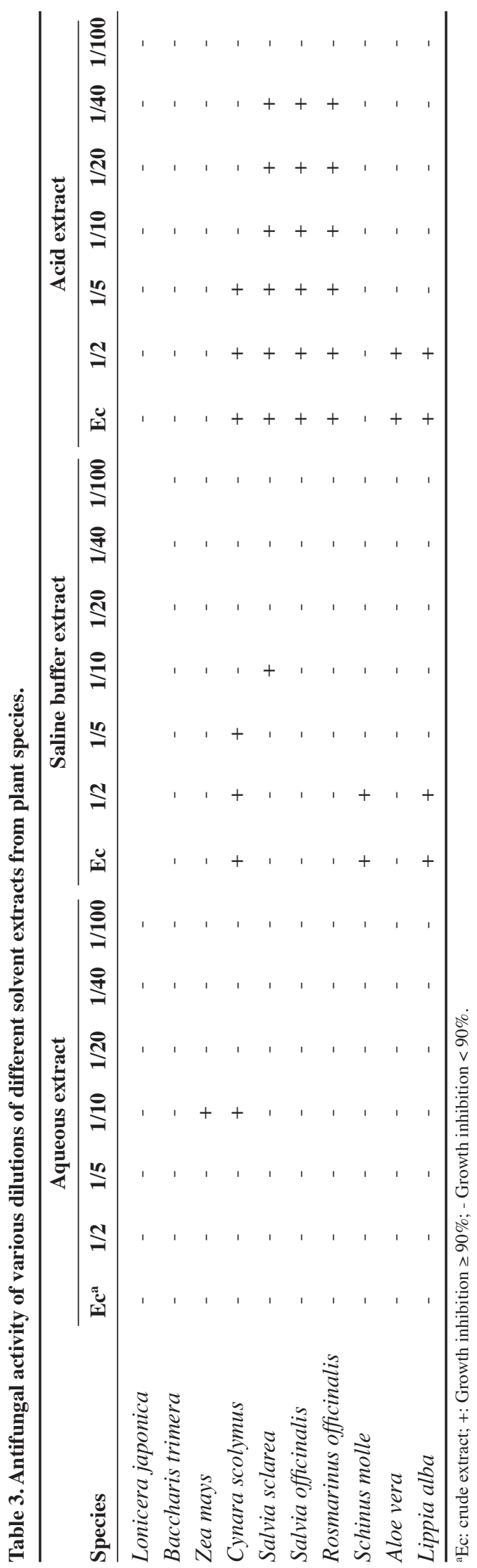

in minor proportion in a plant (Davicino et al., 2007). Conversely, in our case, when crude aqueous extracts of $Z$. mays and $C$. scolymus were tested, the inhibition growth was lower than $90 \%$, whereas the dilution $1 / 10$ inhibited growth by $95 \%$. This may be due to numerous compounds within the crude extracts interfering with the actions of one another. Once the crude extract was diluted, the inhibiting effect of one extract on the other was significantly reduced. These data indicate that the appropriate extract concentration to show a specific effect depends on the plant used and the nature of the extract. This emphasizes the need to know the compound/s responsible for the inhibitory activity through studies to purify, identify and characterize the biomolecules.

Crude plant extracts are generally a mixture of active and non-active compounds, and MICs of less than $100 \mu \mathrm{g}$ $\mathrm{mL}^{-1}$ suggest good antimicrobial activity (Webster et al., 2008). In this research, all the MICs values were lower than $100 \mu \mathrm{g} \mathrm{mL}^{-1}$, demonstrating strong antifungal activity of extracts under study. Some studies have reported antifungal activity of essential oil, ethanolic and aqueous extracts of S. molle (Dikshit et al., 1986; Schmourlo et al., 2005). However, to our knowledge, this is the first time that buffer extract of this species shows very low MIC values (MIC $25.0 \mu \mathrm{g} \mathrm{mL}^{-1}$ ). The buffer solvent contains some compounds, such as ethylenediaminetetraacetic acid (EDTA), polyvinylpolypyrrolidone (PVPP), phenylmethylsulfonylfluoride (PMSF) and Pepstatin A, which enhance protein extraction. The inhibitory activity against Alternaria spp. is probably due to some extent to antimicrobial proteins/peptides.

Banso et al. (1999) reported that the antifungal substances contained in the extracts were fungistatic at lower concentrations, while becoming fungicidal at higher concentrations of the extracts. Our results indicate that the MFC of the extracts evaluated were obtained at similar or higher concentrations than in the MIC assays, but not at lower concentrations (Table 4). In R. officinalis, the MFC of the acid extract possesses more fungicidal action, as indicated by the low MFC observed. Buffer $C$. scolymus extract has the lowest fungicidal action among the extracts assayed.

The leaf extracts of S. officinalis and R. officinalis and seed extracts of $S$. sclarea showed MIC values lower than those of the chemical fungicide (MIC $2.5 \mu \mathrm{g} \mathrm{mL}^{-1}$ ). We can conclude that these extracts exhibit significant fungicidal properties that support their traditional use as antiseptics (Alonso Paz, 2000; Heinzen et al., 2004). Plants do not contain an immune system and thus must rely on other mechanisms to defend themselves from infection by a variety of pathogens. In the case of fungal infection, these mechanisms include synthesis of bioactive organic compounds (Morrisey and Osbourn, 1999) and antifungal 
Table 4. Minimal inhibitory concentration (MIC) and minimum fungicidal concentration (MFC) of crude extracts from plant species against Alternaria sp.

\begin{tabular}{|c|c|c|c|c|c|c|}
\hline \multirow[b]{2}{*}{$\begin{array}{l}\text { Plant } \\
\text { species }\end{array}$} & \multicolumn{3}{|c|}{ MIC } & \multicolumn{3}{|c|}{ MFC } \\
\hline & $\begin{array}{c}\text { Aqueous } \\
\text { extract }\end{array}$ & $\begin{array}{c}\text { Saline buffer } \\
\text { extract }\end{array}$ & $\begin{array}{c}\text { Acid } \\
\text { extract }\end{array}$ & $\begin{array}{c}\text { Aqueous } \\
\text { extract }\end{array}$ & $\begin{array}{c}\text { Saline buffer } \\
\text { extract }\end{array}$ & $\begin{array}{c}\text { Acid } \\
\text { extract }\end{array}$ \\
\hline \multirow{2}{*}{\multicolumn{7}{|c|}{ Lonicera japonica }} \\
\hline & & & & & & \\
\hline Baccharis trimera & $(-)$ & $(-)$ & $(-)$ & $\mathrm{Nf}$ & $\mathrm{Nf}$ & $\mathrm{Nf}$ \\
\hline Zea mays & 5.0 & $(-)$ & $(-)$ & $\mathrm{Nf}$ & $\mathrm{Nf}$ & $\mathrm{Nf}$ \\
\hline Cynara scolymus & 5.0 & 10 & 10 & $\mathrm{Nf}$ & 10 & $\mathrm{Nf}$ \\
\hline Salvia sclarea & $(-)$ & 5.0 & 1.25 & $\mathrm{Nf}$ & $\mathrm{Nf}$ & 2.5 \\
\hline Salvia officinalis & $(-)$ & $(-)$ & 1.25 & $\mathrm{Nf}$ & $\mathrm{Nf}$ & 2.5 \\
\hline Rosmarinus officinalis & $(-)$ & $(-)$ & 1.25 & $\mathrm{Nf}$ & $\mathrm{Nf}$ & 1.25 \\
\hline Schinus molle & $(-)$ & 25 & $(-)$ & $\mathrm{Nf}$ & $\mathrm{Nf}$ & $\mathrm{Nf}$ \\
\hline Aloe vera & $(-)$ & $(-)$ & 25 & $\mathrm{Nf}$ & $\mathrm{Nf}$ & $\mathrm{Nf}$ \\
\hline Lippia alba & $(-)$ & 25 & 25 & $\mathrm{Nf}$ & $\mathrm{Nf}$ & $\mathrm{Nf}$ \\
\hline
\end{tabular}

(-): No inhibitory activity; Nf: No fungicidal activity.

proteins (Selitrennikoff, 2001) and peptides (Broekaert et al., 1997). The quantity and quality of these active compounds depends on the plant species, plant tissue under study and environmental factors (Demo and Oliva, 2008; Webster et al., 2008).

\section{CONCLUSIONS}

The results obtained from this work showed that plant extracts of Uruguayan medicinal plants screened exhibit antifungal effects against Alternaria sp. In particular, acid extracts of Salvia sclarea, Salvia officinalis and Rosmarinus officinalis offer effective bioactive compounds for growth inhibition of the fungi. Even at low concentrations, these species showed antifungal activity nearly equal to that of the commercial fungicide used as a positive control.

Further studies are needed to determine the chemical identity of the bioactive compounds responsible for the observed antifungal activity. Natural plant-derived fungicides may be a source of new alternative active compounds, in particular with antifungal activity. The high proportion of active extracts in the assayed species, selected according to available ethnobotanical data, corroborates the validity of this approach for the selection of plant species in the search for a specific activity.

\section{ACKNOWLEDGEMENTS}

This work was supported by INIA Uruguay (Research Project BT_04). We are grateful to Nora Altier and Carolina Leoni from the Plant Protection Department
(INIA Las Brujas) for supplying the fungus isolates and José Villamil who provided the plant material. We are thankful for the revisions of the English manuscript by Rafael Narancio. P.D.D. was the recipient of a Ph.D. scholarship and A.C. was the recipient of degree scholarship, both from Agencia Nacional de Investigación e Innovación (ANII, Uruguay).

\section{RESUMEN}

Actividad antifúngica de extractos de plantas medicinales contra el hongo fitopatógeno Alternaria spp. El objetivo de este trabajo fue evaluar la actividad antifúngica de extractos vegetales de 10 especies utilizadas en la medicina tradicional uruguaya contra el hongo fitopatógeno Alternaria spp. Las plantas fueron seleccionadas en base a usos etnobotánicos reportados. Se evaluó in vitro la actividad antifúngica de tres tipos de extractos, acuoso, tampón salino de extracción y ácido, de las diferentes especies vegetales. Para la evaluación de la actividad antifúngica se usó un ensayo microespectrofotométrico. Para los extractos se determinaron los parámetros de mínima concentración inhibitoria (MIC) y mínima concentración fungicida (MFC). Los tres solventes utilizados fueron ensayados en diferentes órganos vegetales; de los 29 extractos evaluados, el $31 \%$ presentó una inhibición del crecimiento en Alternaria spp. similar a la de un fungicida químico. Los extractos ácidos fueron los más efectivos. Los valores de MIC obtenidos variaron entre 1,25 y $25,0 \mu \mathrm{g} \mathrm{mL}^{-1}$. Para MFC se observaron valores en el rango de $1,25 \mu \mathrm{g}$ $\mathrm{mL}^{-1}$ (Rosmarinus officinalis L.) y $10,0 \mu \mathrm{g} \mathrm{mL}^{-1}$ (Cynara 
scolymus L.). Los valores de MIC y MFC de extractos obtenidos de hojas (Salvia officinalis L. y R. officinalis) y semillas (Salvia sclarea L.) fueron comparables a los valores obtenidos con el fungicida convencional captan $\left(2,5 \mu \mathrm{g} \mathrm{mL}^{-1}\right)$. Los extractos de $S$. sclarea, S. officinalis y $R$. officinalis pueden ser fuentes potenciales de compuestos antifúngicos para el tratamiento de enfermedades en plantas. Estos extractos mostraron máxima actividad inhibitoria a bajas concentraciones, teniendo un comportamiento similar a la del fungicida químico. Estos resultados permiten concluir que estos extractos presentan sorprendentes propiedades fungicidas, fundamentando su uso tradicional como antisépticos.

Palabras clave: propiedades fungicidas, usos etnobotánicos, Uruguay.

\section{LITERATURE CITED}

Abril, M., K.J. Curry, B.J. Smith, and D.E. Wedge. 2008. Improved microassays used to test natural productbased and conventional fungicides on plant pathogenic fungi. Plant Disease 92:106-112.

Agrios, G.N. 2004. Losses caused by plant diseases. p. 29-45. Plant Pathology. Elsevier, Oxford, UK.

Alonso Paz, E. 2000. Investigación sobre uso popular de plantas medicinales en la zona de Pedernal. 28 p. Centro Uruguayo de Tecnologías Aplicadas CEUTA, Montevideo, Uruguay.

Banso, A., S.O. Adeyemo, and P. Jeremiah. 1999. Antimicrobial properties of Vernonia amygdalina extract. Journal of Applied Science and Management 3:9-11.

Broekaert, W.F., B.P.A. Cammue, M.F.C. De Bolle, K. Thevissen, G.W. De Samblanx, and R.W. Osborn. 1997. Antimicrobial peptides from plants. Critical Reviews in Plant Sciences 16:297-323.

Broekaert, W.F., F.R.G. Terras, B.P.A. Cammue, and J. Vanderleyden. 1990. An automated quantitative assay for fungal growth inhibition. FEMS Microbiology Letters 69:55-60.

Cowan, M.M. 1999. Plant products as antimicrobial agents. Clinical Microbiology Reviews 10:564-582.

Davicino, R., M.A. Mattar, Y.A. Casali, S. Graciela, E. Margarita, and B. Micalizzi. 2007. Antifungal activity of plant extracts used in folk medicine in Argentina. Revista Peruana de Biología 14:247-251.

Demo, M.S., and M. Oliva. 2008. Antimicrobial activity of medicinal plants from South America. p. 152-164. In Watson, R.R., and V.R. Preedy (eds.) Botanical medicine in clinical practice. CABI International, Wallingford, UK.
Dikshit, A., A. Naqvi, and A.A. Husain. 1986. Schinus molle: a new source of natural fungitoxicant. Applied and Environmental Microbiology 51:1085-1088.

El-Mahmood, A.M., J.H. Doughari, and N. Ladan. 2008. Antimicrobial screening of stem bark extracts of Vitellaria paradoxa against some enteric pathogenic microorganisms. African Journal of Pharmacy and Pharmacology 2:89-94.

Eloff, J.N. 1998. A sensitive and quick microplate method to determine the minimal inhibitory concentration of plant extracts for bacteria. Planta Medica 64:711-713.

Espinel-Ingroff, A., A. Fothergill, J. Peter, M.G. Rinaldi, and T.J. Walsh. 2002. Testing conditions for determination of minimum fungicidal concentrations of new and established antifungal agents for Aspergillus spp.: NCCLS Collaborative Study. Journal of Clinical Microbiology 40:3204-3208.

Griffin, G.F., and F.S. Chu. 1983. Toxicity of the Alternaria metabolites alternariol, alternariol methyl ether, altenuene, and tenuazonic acid in the chicken embryo assay. Applied and Environmental Microbiology 46:1420-1422.

Guo, B.Z., Z.Y. Chen, R.L. Brown, A.R. Lax, T.E. Cleveland, J.S. Russin, et al. 1997. Germination induces accumulation of specific proteins and antifungal activities in corn kernels. Phytopathology 87:1174-1178

Harris, C.A., M.J. Renfrew, and M.W. Woolridge. 2001. Assessing the risk of pesticide residues to consumers: recent and future developments. Food Additives and Contamination 18:1124-1129.

Heinzen, H., A. Vázquez, E. Dellacassa, J. Villamil, y G. Bittencourt. 2004. La producción y comercialización de fitoterápicos. p. 52-131. Fundaquim, Red Propymes, Uru. Tec., Fundasol, Cooperación Técnica Alemana (eds.) Aportes para el desarrollo del sector de plantas medicinales y aromáticas en el Uruguay. Artes Gráficas, Montevideo, Uruguay.

Itako, A.T., K.R.F. Schwan-Estrada, J.B.T. Júnior, J.R. Stangarlin, and M.E.S. Cruz. 2008. Atividade antifúngica e proteção do tomateiro por extratos de plantas medicinais. Tropical Plant Pathology 33:241-244.

Lipkin, A., V. Anisimova, A. Nikonorova, A. Babakov, M. Bienert, et al. 2005. An antimicrobial peptide Ar-AMP from amaranth (Amaranthus retroflexus L.) seeds. Phytochemistry 66:2426-2431.

Lopes, M.C., and V.C. Martins. 2008. Fungal plant pathogens in Portugal: Alternaria dauci. Revista Iberoamericana de Micología 25:254-256.

Morrisey, J.P., and A. Osbourn. 1999. Fungal resistance to plant antibiotics as a mechanism of pathogenesis. Microbiology and Molecular Biology Reviews 63:708-724. 
Pinelo, M., M.J. Manzocco, M.J. Nunez, and M.C. Nicoli. 2004. Solvent effect on quercetin antioxidant capacity. Food Chemistry 88:201-207.

Pose, G., V. Ludemann, J. Segura, and V. Fernández Pinto. 2004. Mycotoxin production by Alternaria strains isolated from tomatoes affected by Blackmold in Argentina. Mycotoxin Research 20:80-86.

Rivillas-Acevedo, L.A., and M. Soriano-García. 2007. Isolation and biochemical characterization of an antifungal peptide from Amaranthus hypochondriacus seeds. Journal of Agricultural and Food Chemistry 55:10156-10161.

Satish, S., D.C. Mohana, M.P. Ranhavendra, and K.A. Raveesha. 2007. Antifungal activity of some plant extracts against important seed borne pathogens of Aspergillus sp. Journal of Agricultural Technology 3:109-119.

Schmourlo, G., R.R. Mendonça-Filho, C.S. Alviano, and S.S. Costa. 2005. Screening of antifungal agents using ethanol precipitation and bioautography of medicinal and food plants. Journal of Ethnopharmacology 96:563-568.
Selitrennikoff, C.P. 2001. Antifungal proteins. Applied and Environmental Microbiology 67:2883-2894.

Terras, F.R.G., H.M.E. Schoofs, M.F.C. De Bolle, F. Van Leuven, S.B. Rees, J. Vanderleyden, et al. 1992. Analysis of two novel classes of plant antifungal proteins from radish (Raphanus sativus L.) seeds. Journal of Biological Chemistry 267:15301-15309.

Webster, D., P. Taschereau, R.J. Belland, C. Sand, and R.P. Rennie. 2008. Antifungal activity of medicinal plant extracts; preliminary screening studies. Journal of Ethnopharmacology 115:140-146.

Wilson, C.L., J.M. Solar, A. El Ghaouth, and M.E. Wisniewski. 1997. Rapid evaluation of plant extracts and essential oils for antifungal activity against Botrytis cinerea. Plant Disease 81:204-210.

Zhu, X.F., H.X. Zhang, and R. Lo. 2005. Antifungal activity of Cynara scolymus L. extracts. Fitoterapia 76:108-111. 